\title{
OPROEP AAN KERAMIEKVERZAMELAARS
}

Nederland telt vele duizenden keramiekverzamelaars. Sommigen verzamelen heel breed, anderen hebben alleen belangstelling voor een bepaald type keramiek, voor een bepaalde periode of stijl, of zelfs voor een enkele kunstenaar of producent. Wat zij met elkaar delen is de liefde voor het keramische object, voor de vormen, het materiaal, de glazuren.

VEEL MUSEA DANKEN hun bestaan aan verzamelingen die ooit met veel zorg en inzicht door deze particulieren bijeengebracht zijn. Dat geldt ook voor het Princessehof Leeuwarden, Nationaal Keramiekmuseum. De omvangrijke verzameling oosterse keramiek van de notaris Nanne Ottema (1874-1955) vormde in 1917 de grondslag van dit museum.

EIND 2004 ORGANiSEert het Princessehof een grote tentoonstelling over hedendaagse Nederlandse keramiekverzamelaars. Deze tentoonstelling, waarmee het museum na een grootscheepse verbouwing wordt heropend, toont niet alleen de mooiste, verrassendste, opmerkelijkste en dierbaarste stukken uit verschillende particuliere collecties, maar laat vooral ook de verzamelaars zelf aan het woord. Het museum is geïnteresseerd in hun beweegredenen om keramiek te gaan verzamelen, in het verhaal over hun allereerste stuk, in de criteria die zij hanteren bij aankopen en in de wijze waarop zij met hun verzameling leven en omgaan.

BENT U KERAMIEKVERZAMELAAR en heeft $u$ belangstelling om een bijdrage te leveren aan het onderzoek dat aan deze tentoonstelling voorafgaat, dan kunt u contact opnemen met het museum voor toezending van een vragenlijst:

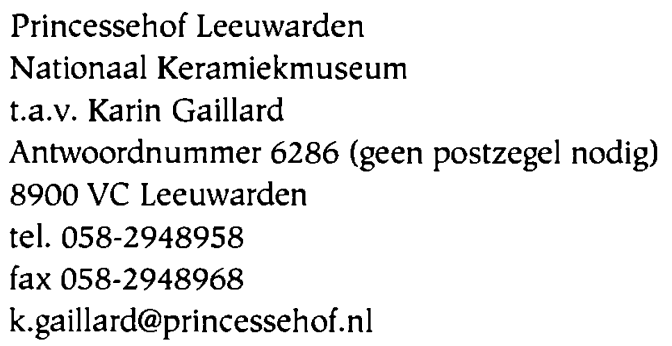

De vragenlijst kunt u ook downloaden via de website van het museum, www.princessehof.nl en per e-mail terugsturen naar info@princessehof.nl 